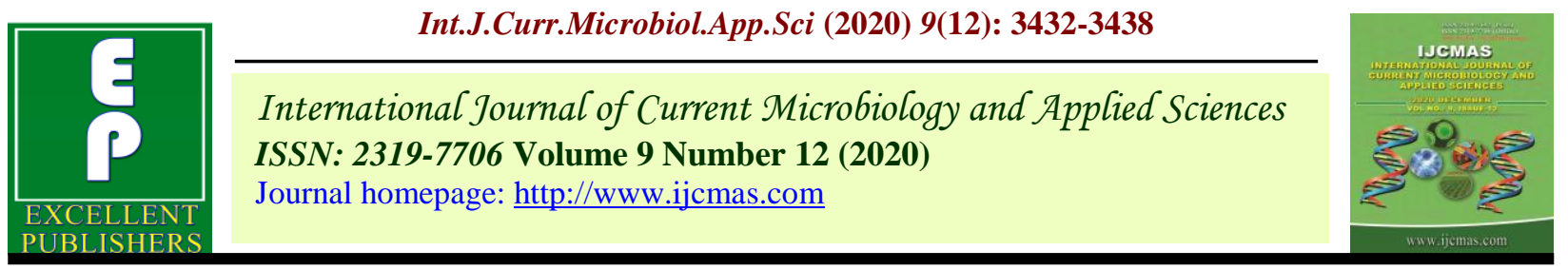

Review Article

https://doi.org/10.20546/ijcmas.2020.912.408

\title{
Social and Digital Media Utilization by NGO's for Uplifting Farming Community in UT of Puducherry
}

\author{
S. Parthasarathi*, P. Sanjith Kumar, B. Prathab, M. Periyasamy, \\ A. Pouchepparadjou and A. Shaik Alauddin
}

\author{
Department of Agricultural Economics and Extension, Pandit Jawaharlal Nehru College of \\ Agriculture and Research Institute, Karaikal, India \\ *Corresponding author
}

\begin{tabular}{|l|}
\hline Ke y w or d s \\
NGO, Perception, \\
$\begin{array}{l}\text { Social and Digital } \\
\text { Media, } \\
\text { Development }\end{array}$ \\
\hline Article Info \\
\hline $\begin{array}{l}\text { Accepted: } \\
\text { 04 November 2020 } \\
\text { Available Online: } \\
10 \text { December } 2020\end{array}$ \\
\hline \hline
\end{tabular}

A B S T R A C T

Social and digital media facilitates effective communication by sharing ideas, thoughts and information through virtual networks among rural communities. Social media use by the farmers is inevitable and enhances them to interact with their neighboring community, officials, market, and other development agencies. NGOs, a major player in rural development and serves the objective to work with the community are harnessing the benefits of social and digital media by establishing strong relations with people and organizations. NGO's explores various dimensions of social and digital media to interact with their beneficiaries. With this background, a study was conducted to explore the social and digital media initiatives for rural development with the dimensions of social and digital media utilization pattern, preferences of beneficiaries, perception about social media, type of information sought by rural people. The study was conducted by analyzing the activities of three reputed NGOs, viz., DHAN, MSSRF, and CEAD functioning in the U.T of Puducherry. The officials and beneficiaries of the NGOs were examined for this analysis. The results show that most NGOs use social media to share technical information related to crop production/animals husbandry followed by marketing information, weather, and training related information. The officials of NGOs and beneficiaries perceived that these media are beneficial for rural development. The important barriers expressed by them include language of message, digital literacy, cost of access data and connectivity. The suggestion offered by them includes training in ICT, internet speed, proper translation of messages in local language. The acceptance towards social and digital media is positive to a considerable utilization from the NGOs and farmers. The respondents admitted that social and digital are effectively transfer the information and technology, easy to operate, cover large number of farmers, ensures timeliness in access to send and receive information, an effective mechanism to manage the dearth of staff in NGO's and cost effective. At contrast due to the education level of farmer/rural people, income, experience in handling ICT tools, social and digital media failed to be an effective teaching tool, convince rural people towards the information reliability, and reach farmers without discrimination. 


\section{Introduction}

Social and Digital media facilitates the sharing of ideas, thoughts, and information among various stakeholders of rural and urban communities. It is the most feasible form of digital communication and it is a great platform to start any conversation, connect with people cutting across boundaries, age groups, spatial differences in rural communities in particular.

The NGOs serving in rural areas are instrumental in the formation and capacity building of stakeholders of farm and allied activities and are accepted as an effective machine for rural development. Social media provides a platform for the development sector especially NGO's a chance to get close community by communication through which they can interact, listen and engage constituents.

It enables them to network with colleagues and stakeholders and deepen their relationships. Akatay (2017) reported that NGOs prefer SMS to send information to stakeholders. Nchabeleng (2018) revealed that $70 \%$ of respondents are positively agreed that social media is relevant in promoting NGO activities. Jagoda Prętnicka-Markiewicz (2018) inferred that $92 \%$ of NGOs have their own Facebook page, nearly $70 \%$ have a Twitter account, and almost $40 \%$ are present on Instagram.

Facebook is the most popular social media platform with $92 \%$ of NGOs around the world using it to connect with its dependents (Devyani, 2019). With this background, the study was formulated to explore the various social and digital media initiatives for rural development and conducted as a case study through analyzing the activities of three major NGOs functioning in the U.T. of Puducherry viz., DHAN, MSSRF, and CEAD.
In order to explore the social and digital media utilization for rural upliftment by NGO's a study was conducted through NGOs functioning in the rural areas of Puducherry district and Karaikal district of UT of Puducherry viz., DHAN, MSSRF and CEAD. A focus group discussion was carried out with officials and beneficiaries of the above three NGO's to explore the important contribution of social and digital media for the upliftment of rural people in the study area.

\section{Social and Digital Media application by NGOs}

\section{Development of Humane Action (DHAN)}

The Development of Humane Action (DHAN), a professional development organization functioning since October 2, 1997, in 16 states of India.

The mission statement of the organization is building people and sustainable institutions with value-driven, ethical, and democratic processes to enable the poor for poverty eradication, nutrition security, inclusive and ecologically balanced development. It brings highly motivated young educated professionals to the development sector. from the mainstream financial institutions and commercial banks by providing timely assistance.

The study focuses on the institution namely Kalanjiyam Development Financial Services (KDFS) a development financial institution set up by DHAN Foundation mainly to bridge the gap due to delay in the sanction of loans.

The discussion was made with the beneficiaries and officials of Thirunallar Vattara Kalanjiyam located in the Karaikal district of U.T. of Puducherry. 
Narration of social media initiatives of DHAN

DHAN Mostly used social media namely WhatsApp, Facebook, Youtube, Twitter, and Instagram to share the information quickly among officials, beneficiaries, and other stakeholders. It has an exclusive program called ICT for the poor to promote digital literacy and other ICT-related activities.

DHAN very often uses Whatsapp to share information with farmers with three main groups namely call resilience, DHANNagapattinam, Thirunallar Vattara Kalanjiyam. Call resilience group is involved with only officers and staff of the foundation. DHAN Nagapattinam group is mainly functioning for 8 regional staff. Thirunallar Vattara Kalanjiyam group includes local staff and 7 leaders of Thirunallar Vattara Kalanjam.

Agricultural-related information on organic farming, mushroom cultivation, goat farming, integrated farming system, buying and selling of products, variety of seeds and green fodder practices, and information about health management, women empowerment, and water themes are being posted and discussed in these Whatsapp groups.

DHAN Foundation has been maintaining a Facebook page to share information on agriculture technology and allied activities, orientation programs, health issues, livelihood and women empowerment, and other programs of DHAN.

DHAN has been uploading videos in its own Youtube channel "DHAN FOUNDATION" since July 182008 and used to share videos containing technologies includes success stories of various development programs, organic farming, disaster management education, training information, and other promotional activities. This Youtube channel has uploaded 138 video information with 1.9 Thousand subscribers and it has 1,61,661 views so far.

\section{Radio}

DHAN Foundation broadcasting a radio service called Kalanjiam Community Radio (Kalanjiam Samuga Vanoli) a unit of Kalanjiam Media Centre as part of its development program in the Tsunami affected areas in Southern India. The Station has been functioning since October 2005. This radio service was funded by United Nations Development Programme provided resources under its Tsunami Recovery Support Programme.

\section{Website}

DHAN shares information through their website WWW.dhan.org. It is Inclusive of all details pertaining to DHAN foundation viz., enewsletter, link to various media, other documents related to DHAN.

\section{Training related to Social and Digital Media}

DHAN organized training programs through Kalanjiyam Thozhilagam limited to farmers on buying and selling agricultural commodities online and offline.

\section{Preference of beneficiaries}

Women KDFS members predominantly prefer timely information through Whatsapp at a regular interval. The same media was preferred by marginal and small farmers under various agricultural developmental schemes. Information on KDFS activities followed by agriculture, marketing, health, and finance was the most preferred information by the members. Those beneficiaries who were availing support for production and marketing 
of produces prefer market trend, price, and stock availability.

\section{M.S. Swaminathan Research Foundation (MSSRF)}

M. S. Swaminathan Research Foundation (MSSRF) was established in 1988 as a nonprofit trust. The foundation aims to accelerate the use of modern Science and Technology for Agriculture and Rural Development to improve the lives and livelihood of communities.

Also follows the pro-poor, pro-women, and pro-nature approach and applied appropriate Science and technology options to address practical problems faced by the rural population in agriculture, food, and nutrition. The study was confined to the Bio-Village Resource Center located in the Puducherry district which aims to accelerate the use of modern science and technologies for agricultural and rural development to improve life and livelihood.

Narration of Digital and Social media initiatives of MSSRF

\section{Mobile Phone}

The MSSRF Puducherry has been sharing agriculture information with farmers by calling them on phone. 1600 registered farmers from 30 villages are the beneficiaries of this service. The farmers are getting the information weekly twice from the foundation between 10:30 a.m. to 11 a.m. for a minute duration. The MSSRF Puducherry gives information based on crops such as paddy, vegetables, and flowers.

MSSRF has developed a Mobile Application for fishing farmers called "Fisher Friend Mobile Application" in 2007 later upgraded to the Android Mobile platform. The Mobile
Application has providing fishermen with immediate access to critical, near real-time knowledge and information services on weather, potential fishing zones, ocean state forecasts, market-related information, and Government Schemes and Entitlement. MSSRF Puducherry organizing frequent training programs on FFMA for the fishing farmers to get used to the application.

\section{WhatsApp}

MSSRF Bio-Village Resource Center is also communicating with farmers and other rural people through WhatsApp through the following three groups.

The Velaan Thagaval Sevai group consists of 255 members from various districts of Puducherry and Tamil Nadu. The group has been the platform for both farmers and the officials of the foundation to discuss agriculture and related information, queries, solution, suggestions, and prescriptions. The Experimental Farmers group consists of 25 farmers and KVK officials as members. This group was managed to discuss the scientific methods and new techniques for the highly skilled farmers who try to experiment in their land.

The Control Groups comprises 63 farmers and officials who were discussing in-organic agricultural technologies. The TVR Noolaga Vivasaayigal WhatsApp group was created to promote interaction among farmers and other rural people who regularly visited the TVR library located in the Bio-Village Resource Center.

The officials and other members who were managing the WhatsApp groups by sharing the information received from various platforms such as YouTube, Facebook, field experiences, and relevant information from other similar groups. 


\section{CD-ROM}

MSSRF Puducherry was used to share information with farmers with the help of interactive CD-ROM once a month for crops grown in that region. At present, the CD-ROM usage is reduced to a greater extent because of difficulty in handling and shifting of preference to media such as Youtube.

\section{Training related to Social and Digital Media}

MSSRF has developed a Mobile Application for fishing farmers called "Fisher Friend Mobile Application" in 2007 later upgraded to the Android Mobile platform. This application was established with specialized features and services to share information about the fishing field information in all aspects.

The Mobile Application has providing vulnerable fishermen immediate access to critical, near real-time knowledge and information services on weather, potential fishing zones, ocean state forecasts, marketrelated information, and Government Schemes and Entitlement. MSSRF Puducherry organizing frequent training programs on FFMA for the fishing farmers to get used to it.

\section{Preference of beneficiaries}

The information shared in the social and digital media especially through phone calls and Whatsapp were mostly preferred by the small farmers followed by marginal farmers and farm women. Crop varieties, traditional agricultural practices, pest and disease control, weather condition, environmental information, Government schemes, and agriculture policies and plans were the major queries asked by the farmers through social media. The reception of business, trade, market, and credit facilities of institution information was seldom inquired by the farmers.

\section{Centre for Environment and Agricultural Development (CEAD)}

Centre for Environment and Agricultural Development (CEAD) is a Puducherry-based non-governmental organization started in 2003 and with the objective to develop communities particularly women and landless laborers through training in environmentally sustainable income generation activities, introducing microcredits, and improving their access to quality education and health services.

\section{Narration of Social/Digital Media Initiatives}

CEAD Puducherry very often shares agricultural-related information to the farmers of Puducherry through social and digital media. The organization has been sharing Information through Whatsapp groups namely CEAD NGO, CEAD Iyarkkai Velaanmai, and CEAD Training.

The CEAD NGO WhatsApp group has got 256 members as beneficiaries. The group mainly used to share the information on CEAD activities and discussing the queries raised by farmers.

The CEAD Iyarkkai Velaanmai (CEAD Organic Farming) Whatsapp group is used to share and discuss organic farming information and queries among 175 farming members and the official of CEAD. The CEAD Training was WhatsApp group has started to share information on new ideas and recommendations to bring up the unemployed youths of Puducherry to start their own business. The organization also surfs Facebook and YouTube from various sources to gather information to send farmers.

The CEAD has also harnessed the potential of Television media. They used to share their 
views, advice, and recommendation information to farmers and farming entrepreneurs through regional TV channels namely Makkal TV, Thamizhan TV, Podhigai TV, and Thandhi TV.

\section{Preference of beneficiaries}

The agriculture-related information shared by CEAD had been mostly received by small farmers followed by marginal farmers, entrepreneurs. Entrepreneurs prefer regular information through social and digital media among categories that depend on farming. The WhatsApp groups have got more responses for sharing agriculture and entrepreneurshiprelated information. Next to that, horticulture, animal husbandry, market, and weatherrelated information were sought by beneficiaries through social and digital media.

\section{Format of the information that farmers like to share and receive}

Farmers like to receive information in an audio and visual format. The complete interpretation with both audio and visual information leads much in understanding by the farmers towards the information they receive. Next to that, audio format information like voice recording and audio forward messages is mostly preferred by farmers. The majority of the farmers like to raise queries through WhatsApp with the query of voice recording audio along with a photo of their crop issue.

\section{Perception towards social and digital media}

The perception towards the application of social and digital media is positive to many of its usage. The respondents agreed that social and digital media effectively transfer the information and technology, easy to handle, cover more farmers, ensure timeliness of information, an effective mechanism to manage the dearth of staff in NGO's and costeffective.

On contrary, easy to convince rural people, reach farmer without discrimination effective teaching tool was perceived negatively by the respondents. While perusing their reason for disagreement to the above said statements, education level of farmer/rural people, income, experience in handling ICT tools were put forth by them as reasons.

\section{Constraints faced by NGOs}

The following are the constraints commonly faced by all the three NGOs while adopting social and digital media technology among beneficiaries.

Lack of knowledge in accessing social media by the farmers was a major constraint. Though farmers were interested in getting information through social and digital media, the majority of them were not able to access information due to a lack of digital literacy.

The cost involved in the purchase of gadgets like smartphones and laptops were preventing farmers access information through these media.

Most of the technical information available in the English language is the next major constraint. If the message is in other than Vernacular language, the farmers were unable to read the message and they lose interest in reading, viewing, and hearing the information through these media.

Inadequacy of internet speed in rural areas halt the farmer interest in these media.

Posting information very often in WhatsApp groups distract the farmers, and finally, they were losing interest in receiving any information from these media. 
Suggestions for better utilization of Social and Digital media

Educating the farmers on digital literacy especially to use smartphones and access social media by conducting workshops.

Translate and disseminate the information from other languages to the Tamil language can bring up the farmers to access all kinds of information. A separate television channel for Agriculture in the Tamil language may be started since television is the most utilized digital media in rural areas. Telecasting Agriculture-related television series and web series can bring up the farmers to gain more interest and ideas. Providing ICT gadgets and internet connection at a subsidized rate may enhance the farmers/ rural people to access more information through these media.

Educate the students of the rural area. Through that, they can train their family especially the parents to access the media and information. Application of social and digital media is inevitable in all sphere of development. The scope for utilizing these media for transforming people living in rural area especially by the NGOs is wider. The strong network established by the NGOs will speed up the technology transfer, connecting communities and thus reach their goals.

\section{Acknowledgement}

The authors acknowledge the financial support of ICSSR for funding under IMPRESS
Scheme to undergo this case study. The authors acknowledges the contributions by Th. P. Balasubramaniyam, Project Executive, KDFC, DHAN Foundation, Karaikal, Dr. C. Ganache, Director, CEAD Puducherry and Mrs. D. S. Girija, Development Coordinator, VKC, MSSRF, Puducherry.

\section{References}

Akatay, A., 2017. A Qualitative Research on Ngos' Use of Social Media in Çanakkale. Route Educational and Social Science Journal, 4(19), 63-80. https://doi.org/10.17121/ressjournal.84 3

Devyani, R. 2019. Here is how NGOs are using social media for change, Retrieved from https://blog.giveindia. org/social-media-for-change/here-ishow-ngos-are-using-social-media-forchange/, September 10, 2019.

Jagoda Prętnicka-Markiewicz. 2018. How global non-governmental organizations use social media. Retrieved from https://sentione.com/blog/how-globalngos-use-social-media, on 22 Feb 2018.

Nchabeleng, G., Botha, CJ. and Bisschoff, C. 2018. The Use of Social Media in Public Relations at Non-Governmental Organisations in South Africa. Journal of Economics and Behavioral Studies, 10(6), 150. https://doi.org/10.22610/ jebs.v10i6.2605

\section{How to cite this article:}

Parthasarathi, S., P. Sanjith Kumar, B. Prathab, M. Periyasamy, A. Pouchepparadjou and Shaik Alauddin, A. 2020. Social and Digital Media Utilization by NGO's for Uplifting Farming Community in UT of Puducherry. Int.J.Curr.Microbiol.App.Sci. 9(12): 3432-3438. doi: https://doi.org/10.20546/ijcmas.2020.912.408 